\title{
2. The String Bag of the Tambaran: The fragile loops of concealing and revealing in Abelam culture
}

\author{
Brigitta Hauser-Schäublin
}

\section{Introduction}

Some things only become clear with hindsight. This goes for my own fieldwork in the Sepik area (between 1972 and 1983), and it is probably true of other anthropologists as well, many of whom, as I gather from their writings, went through the same difficulties as I did. When I set out for Papua New Guinea, I took with me a pre-postmodern conception of 'culture', fuelled by the fascination for other, preferably still 'autochthonous' world views and agency in faraway societies. This predisposition often made it difficult to grasp what appeared to me in my understanding of 'culture' as seemingly precipitate and unexpected actions by the people I was living with, and to reflect on them and class them in terms of scientific concepts.

I was reminded of this when reading Don Tuzin's The Cassowary's Revenge (1997); it brought back memories of events during my fieldwork among the Abelam (between 1978 and 1983), which at the time had shocked and scared me. I came to realise that a new era had begun in Papua New Guinea, an era and setting in which I no longer wished to conduct fieldwork - nor was I any longer willing to take the risk.

Against the background of the socially disruptive events that Tuzin describes for the Ilahita Arapesh, complemented by three personal experiences of my own, I set out in this contribution to develop and describe a systemic principle upon which I believe Abelam culture is based. At the risk of falling prey to a 'lurking functionalism' (Roscoe 1995:4) or, even worse, a furtive structuralism, I shall address the issue of cultural aesthetics - similar to what Anthony Forge (1966, 1970, 1973) attempted for the field of art. I focus on the Tambaran cult ${ }^{1}$ as still

\footnotetext{
1 By Tambaran (Tok Pisin), the Ilahita Arapesh describe everything 'that men do'. Tuzin calls the Tambaran cult a 'cult of war and human sacrifice' with a 'misogynistic ("woman hating") rhetoric'. Tambaran refers to all initiation grades and the ritual paraphernalia used as well as the spirits associated with the cult (Tuzin 2001:11-15). In contrast with the Ilahita Arapesh, the Abelam use the term 'maira' to cover everything mysterious, secretive and sacred. I shall use Tambaran in this contribution in the sense of a lingua franca term common in the Maprik area.
} 
practised by the Ilahita Arapesh and the Abelam in the 1960s and 1970s from an eccentric perspective, concentrating mainly on the structural foundation of these male cults, which hinge on the notion of secrecy and concealment. The starting point of my analysis is the string bag (Abelam: wut, Tok Pisin: bilum), a 'typical' Abelam product that is manufactured by women. I go on to show that the string bag conjoins two systemic principles: on the one hand, its structure, involving a looping technique that relies on the use of a single twine; on the other, its texture, with its transparent character that reveals only a partial view of the inside - that is, of the string bag's contents. I argue that Abelam men's knowledge, which, at the core, is founded on secrecy and concealment, is organised on the same two principles. The interplay between revealing and concealing and the inter-looping of the two modes characterise the hierarchically structured body of social knowledge; at the same time, they relate to a reality that lies beyond the world of everyday life with its routine processes and practices that are, by and large, controlled by human agents.

In making this argument, I see many similarities with the contributions by both Birth and Herdt (this volume), though these authors argue from a different theoretical perspective. The Tambaran's string bag is located in male ritual secrecy, when men collectively create objects - string bags of a different quality - that are presented to the uninitiated as mysterium or, as Birth puts it, the 'uncanny'. Thus, men create something new from that which exists out there in the real world (string bags manufactured by women), thereby producing their own truth and their own cultural reality. With the Tambaran's string bag, men also aim at attracting or impressing women and, at the same time, keeping them out of their ritual domain (see Herdt, this volume). Whether they succeed is another question, with which I cannot deal in this chapter.

As I hope to show, the string bag of the Tambaran bundles the socially hierarchically structured knowledge and governs social access to it. I argue further that the mode of handling knowledge - probably typical for the Maprik area as a whole - and the way the keepers of this knowledge revealed it to specific groups, step by step, were linked to the specific social and historical conditions of Maprik cultures that I define as the 'pre-modern'. This situation was superseded by a new era shaped by colonialism, Christian proselytisation, political independence and the advance of a capitalist economy and globalisation. As Tuzin describes so well in The Cassowary's Revenge, the people of the Maprik area were determined to put an end to the 'pre-modern' and to usher in a new, completely different era, which was to be played by new rules and in which the old string bag of the Tambaran had run its course. ${ }^{2}$

2 Where not noted otherwise, I rely on ethnographic data that I collected mainly in Kalabu (HauserSchäublin 1989a). 


\section{The Shock of Other Modernities}

Essentially, there were three separate episodes that left me shattered in my selfunderstanding as an anthropologist and prevented me from conducting further fieldwork in Papua New Guinea once I had finished my research among the Abelam. I was simply no longer prepared to take the risk. The first episode refers to an evening-long discussion with a young man (from the hamlet we were living in) who came to visit us at our house. In the course of our talk, he described in full detail-but retaining an utterly friendly, chatty tone-how he and a group of young men, all of them out of work at the time, had once killed a man and, on a second occasion, a woman during a stay in one of the coastal towns, for absolutely no reason, and not in anger, simply because they felt bored. The murders were never solved. The young man whom we knew otherwise as a gentle-minded young Abelam man showed absolutely no remorse; he was simply telling us his stori ('story'), albeit a little different to the accounts we otherwise heard from old men about the 'earlier days' (Tok Pisin: taim bipo).

But why was he telling us all this? Was there a faint touch of threat in his words? Would he be capable of murdering us too one night, again for no apparent reason? In the other two episodes, we were involved directly.

In 1979 we went with two old men to a neighbouring village that we had visited several times before. The people there were planning to stage a brideprice ceremony, and I wanted to document the event that was being held at the ceremonial ground. I was sitting on the floor, concentrating on what was going on, making sound recordings and taking photographs, when, suddenly, I found a group of young men standing in front of me. Their leader addressed me in English. He ordered me to pack up my tape recorder and all my other equipment and leave immediately. I found myself surrounded by about a dozen young men whom I had not noticed before because I had been concentrating on the adult men and the elders who were responsible for the ceremony. The speaker of the group was wearing boots, long trousers and a white long-sleeved shirt and stood before me, threateningly. There was no doubt: the situation was serious. None of the others understood what he was saying, but from his harsh tone they must have realised what was going on. After many months of speaking Tok Pisin only, I found it hard to switch to English, but in stuttering words I tried to explain to him why I was here and what I was doing. He did not, however, accept the argument that I was documenting traditional knowledge and oral traditions still known to the old people in order to safeguard it for future generations. 'We need roads, economic development, the opportunities to earn money, to grow cash crops,' he answered coarsely. 'We know how the old folks used to live, and what they know we have known for a long time. What are you doing for us?' he asked provocatively. 'Your work will be full of lies just like that of that English 
woman and that German man who were here before you, ${ }^{3}$ and it is not going to help us in any way. We don't need you Whites! Piss off! Pack your things or otherwise we'll destroy them!' He took a threatening step towards me in his heavy boots.

It was a close shave but the situation was resolved when I called for the village councillor who had the power to decide whether a person should leave the village or was allowed to stay. He told me to stay, after which the group of angry young men dispersed (see also Hauser-Schäublin 2002).

In the second episode, together with a group of artists from Kalabu, we were on our way to the Arapesh village of Yamel to visit a location in the mountains that was one of the main sources of the white pigment (sabyo) used by Abelam artists. The Abelam had obtained the pigment there since times beyond memory, and the arrangement was part of the reciprocal relationships between the two villages. When we arrived in Yamel, a few old men waved to us, nodding in agreement when the Kalabu men told them what we had come for. A few younger men got up from the group and accompanied us to the location we were heading for. We finally arrived at the steep mountain slope and, after the painter and his helpers had selected a few chunks of raw, white earth-pigment, the young men from Yamel suddenly confronted us, demanding money. When one of the Kalabu elders objected, maintaining that this was going against an age-old agreement between the two villages, one of the young men rebuked him, saying that the age of the old men was over and that now was the 'time of money' ('taim bilong ol lapun i pinis, nau mani i tok'). From now on, the men would have to pay for the pigment. The young men from Yamel owed no duty of respect to the Abelam elders, so none of them dared to object. There was a long moment of silence. Finally, my husband got out his wallet and paid the demanded fee. We returned to Kalabu immediately without stopping off for the usual polite exchange of compliments.

In both episodes, young men had unmistakably demonstrated rejection, resistance and renunciation: rejection of white people, resistance against the rule of the old men, and renunciation of the traditional ways. These were clear signs of a profound cultural change and the beginning of a new, postcolonial era in which young people (especially young men) looked to the future with high hopes and bright expectations. The traditional Abelam beliefs and practices that had governed the relationships with the old powers and the forces that had, until then, shaped people's lives and doings, including exchange with the ancestors and other supernatural spirits, no longer met the demands of life

3 He was referring to the British-Australian anthropologist Phyllis Kaberry, the first researcher to do fieldwork among the Abelam, in 1939-40, and the German ethnologist Gerd Koch, who undertook a collecting and documentation expedition through the Maprik area in 1966. 
in a young nation-state and fell far short of what young people associated with it. High on the agenda now were economic and political goals that could be achieved only through Western concepts of education and development (see also Sahlins 2005 on this issue). New identities were in demand, and these called for new points of reference.

It is only with hindsight and through drawing on the more recent, general anthropological discourse - the global/local issue, identity and modernities that I came to realise that these young men were caught up in the difficult process of acquiring a new identity and shaping their own view of modernity (see also Gewertz and Errington 2004; Goankar 1999). ${ }^{4}$ There was no room left for traditions and their keepers (see also Jourdan 1996); these were simply blocking the road to the future.

Don Tuzin was not a man to shy away from the challenges that cultural change engendered even though at times he found it difficult to bear, having experienced the fascination of the Tambaran culture during his first fieldwork among the Ilahita Arapesh. In The Cassowary's Revenge, he wrote about Ilahita's renunciation of the Tambaran, with which he had been confronted during his second stay, from 1985 to 1986. He describes how the Ilahita Arapesh 'killed' the Tambaran cult in a public display. It was on the occasion of a Christian revivalist church service on a Sunday in 1984 that the men publicly gave away the secrets of the Tambaran to the women and other non-initiated people, telling them that the male cult had been based on deceit and that the only secret was that there actually was no secret at all (Tuzin 1997:1). Tuzin discusses what social and psychological disruptions this, in his opinion, deliberate and planned public execution, carried out in an atmosphere of millenarian expectations, had on the people. What impressed me about his book, apart from its thick description, was the way in which the author questioned and reflected on his own involvement in this 'Greek tragedy' (Tuzin 1997:64) and on what role his American foreignness, his long, first sojourn in Ilahita between 1969 and 1972, his departure, but also his promise to return had possibly had on the irreversible events. Tuzin not only admitted his indirect involvement, he was also prepared to take over coresponsibility for what happened; at the same time, the book clearly expresses the anthropologist's sorrow and dismay about the loss of culture.

According to Tuzin, one of the gravest consequences this killing and radical abolishment of the Tambaran had was that the men had robbed themselves of the foundations of their masculinity (Tuzin 1997:26,181). With the Tambaran gone, they had lost their means to exert power over women and keep them in check. They had toppled themselves from the throne and were now facing their

4 In his first two monographs, Tuzin did not use the term 'modernity'. Hirsch (2001) rightly asks: 'When was modernity in Melanesia?' 
own vulnerability at the hands of the previously powerless: 'We now know in some detail what happened during the ensuing months, with the Tambaran dead, custom repealed, and the women ecstatically seizing control' (Tuzin 1997:161). The myth of the cassowary woman (Tuzin 1980:11) tells the story of how once a man stole the feather coat of a cassowary woman who was bathing naked in a nearby pool, thus bringing her under his control. Many years later, the woman discovered her feather coat hidden away and was able to escapeback in her shape as a cassowary. Tuzin (1997:176) equates the betrayal of the Tambaran to the women with the return of the feather coat to the cassowary woman - in other words, the setting free of primordial female power and the gaining of independence from male domination. This regained autonomy, which found expression in various new forms of women's behaviour towards men, Tuzin interprets - as the title of his book tells - as the 'Cassowary's Revenge'. ${ }^{5}$ As Tuzin goes on to show, however, this newly won freedom has not made the male-female relationship any easier or better. On the contrary, it has merely led to increasing brutality and more domestic violence (Tuzin 1997:177); at the same time, mothers still treat their sons with harshness.

According to Tuzin, Ilahita village and its culture grew from the interaction between various Abelam and Kwangga groups that successively moved into the area and mingled with the resident Arapesh people, influencing their culture lastingly (see Roscoe, this volume). The Tambaran cult as such, or at least its higher initiation grades, and the ideals of manhood associated with it originated among the Abelam people (Tuzin 1997:4, 84), who began moving into the area about 1870 (Tuzin 2001:15). In fact, the Ilahita initiations as well as the associated Tambaran spirit beings and ritual artefacts (including the ceremonial house) correspond with Abelam ceremonial practice in many respects. In the following, I take my own Abelam data as specific variant of a general Maprik culture that overlaps ethnic groups and languages, with the aim of offering a comparative description. I do not know whether comparable public 'executions' of the Tambaran occurred in other villages of the Maprik area; there are certain clues that suggest similar actions, but maybe not in such radical form. ${ }^{6}$ Between 1995 and 1999, the Maprik Council, the assembly of village councillors - that is, the elected village representatives (Tok Pisin: kaunsel)_-decided

that wild pigs should be hunted down and either exterminated or driven away from the village to the back of the mountains. Semi-domestic pigs were to be put behind fences and could no longer be left wandering around the village or in semi-liberation, or they would be killed too. (Coupaye 2004:150-1)

5 Apparently, and to the dismay of the men, the women were not surprised by the men's 'revelations'. 6 To this, Scaglion (1999:211) says: ‘From the Abelam perspective, real change can only occur cataclysmically via a total restructuring of the world.' The Ilahita Arapesh appear to have fully shared his view. 
In 2001, Coupaye did not see one garden that was fenced in as had been the custom in the old days to keep the pigs out and away from the crops. The ban on pigs was explained on hygienic and safety grounds (aggressive boars) and with the argument that the pigs were reducing productivity by ravaging gardens. This form of utilitarian reasoning ignores the pivotal significance that pigs had in ceremonial life as ritual gifts and sacrificial animals. Coupaye reports that in Nyelikum, his fieldwork site, all the people had become practising Christians ${ }^{7}$ and there was no trace left of traditional ceremonial life, and no ceremonial house. ${ }^{8}$ In Kalabu and in all the other villages of the Maprik area that I used to visit during fieldwork, the sacrifice of pigs used to be a prerequisite for the building of a new ceremonial house and preceded all rituals associated with the cultivation of long yams and/or with initiations. ${ }^{9}$ Even though the Tambaran had not been eradicated as dramatically in other parts of the Maprik area as it had been in Ilahita, the ban on pigs brought an end to all forms of Tambaran activity, since one of the main ceremonial requisites - the sacrifice of pigscould no longer be fulfilled.

\section{The Technology of the String Bag}

As described elsewhere (Hauser-Schäublin 1996), the Abelam are a typical representative of a 'non-cloth culture' in Oceania. ${ }^{10}$ Line, streak, string and frond are the constituent elements in all forms of artistic expression, be it painting or the adornment of human beings, yams, pigs or string bags of various shapes and sizes. In their form-giving and form-defining capacities, the line and string respectively are of central significance (see also Ingold 2007). In Abelam, they go by the same term: maindshe. Maindshe is white, or at least light, if we wish to apply our Western colour criteria to the beige-coloured thread used for making string bags. String is made from the bast fibre (Tok Pisin: mangas; Abelam: sibe) of various plants, preferably from the bark of the yitinbin tree. The bark goes through a number of processing steps until the fibres are twined into string. The Abelam were not familiar with textile techniques other than string bags and plaited mats. ${ }^{11}$ String bags are produced by a looping technique relying

\footnotetext{
7 Ludowic Coupaye, Personal communication, 2007.

8 Google Earth reveals only two or three ceremonial houses left in the entire Maprik area (July 2008).

9 During Coupaye's fieldwork, ceremonial (long) yams were still being grown in Kalabu; for some of the men, they provided an opportunity to gain prestige.

10 Despite the cultural change described briefly above, I shall stick to the ethnographic present when referring to the period between 1978 and 1983. I chose not to use the past tense because I do not know which aspects of the issues I describe are really 'past and gone' and which are still relevant. The ethnographic present reflects a snapshot of things.

11 Abelam men also produce plaited ceremonial mats (these decorate the lower part of the front of the ceremonial house and the projecting roof). Plaiting is based on a different technique (vertical and horizontal elements that are interwoven) to looping; one should therefore distinguish between the two techniques (for example, Coupaye 2004:Ch. 7).
} 
on so-called hourglass looping. Only one string, or thread, is used, to which 'extensions' are attached continuously (see MacKenzie 1991:75-80). Loops are added one by one until the entire fabric, the string bag, is completed. ${ }^{12}$ In contrast with other textile techniques, the string bag displays the following features:

The structure of a looped string bag is differentiated from that of a basket in that it is flexible and laterally expansive. It differs from a woven textile because it requires only one element, simply interworked with itself, to form the fabric, whereas all woven textiles are constructed from two component parts, a warp interlaced with a weft. (MacKenzie 1991:209)

An empty string bag is of almost two-dimensional, trapezoidal shape to which a carrier strap of differing length is attached. When suspended from the apex of the strap-women carry their string bags with the strap passing over the forehead, while men carry their small personal bags over the shoulder - a string takes on an almost triangular shape. But when filled, a string bag becomes an impressively bulgy container that covers its contents like a skin (see also MacKenzie 1991:Plate 89). The term 'wut' describes repositories of different size and fineness, all depending on what they are used for. String bags are always based on the same technology: string looping; this gives the bags their distinctive texture - they are soft, pliable and extremely sturdy. Women carry their babies in string bags, just as they do piglets that have been freshly weaned and which women carry around on their backs in order to accustom them to their new, human environment as a first step in domestication. The large string bags used for carrying firewood and field crops are made of more coarse material and are left undecorated. The finest and most artistic pieces serve to hold the more personal items that men and women carry on them (such as betel-nuts and betel pepper and small lime containers). They are decorated on the front side with the help of red and black-dyed strings displaying patterns of horizontal lines, squares or triangles, and trapezoids respectively, connected by diagonal lines. ${ }^{13}$

\section{The Paradigmatic Character of the String Bag}

A special technological feature of string bags is that they are translucent, providing a partial view of their contents. Men also produce artefacts in the

12 Decoration is added by the simultaneous use of differently coloured threads or by twining such a thread onto the main 'white' thread (Schuster 1989:375).

13 On string-bag patterns from the Iatmul, Kwoma, Sawos and probably also Abelam areas, see Schuster (1989:376-8). 
looping technique (mainly insignia and decorations such as kara-ut, boar-tusk pectorals, and headbands), but they use a needle (made of cassowary bone), which allows them to thread the plied string through very tight meshing. The distinctive texture of the different objects - open versus closed loops - is based on the same technique but follows a gender-specific division of labour (see also MacKenzie 1991:Plates 34 and 35). One also finds this type of 'closure' on the small plaited bags that older men make for themselves, which are also opaque. They use them for their personal belongings; at the same time, they serve as male insignia indicating that the owner has almost completed the full initiation cycle.

In everyday life, the Abelam frequently take advantage of the transparency of string bags. For instance, it shows who presently is in possession of betel-nuts - a much sought-after natural stimulant, which are chewed with betel pepper and lime powder. Among kin and friends, it is absolutely normal to 'feel' a person's string bag to see whether he or she is carrying any betel-nuts. Should this be the case one can ask for one- a request that may hardly be turned down. This means that carrying around a string bag always implies having to be prepared for inquisitive looks and demands.

As Forge (1966, 1971, 1972) and Losche (1995) have shown, wut is also the term used to designate the painted initiation chamber that is constructed within the ceremonial house and into which initiates are taken during initiation ceremonies. The commonplace term for painted palm-leaf sheaths (Tok Pisin: panggal), outside any sacred context, is ' $m b a i$ '. The same term - mbai literally refers to the actual palm-leaf material - is also used to designate the large triangular painting facing the public meeting ground on the facade of ceremonial houses. These facade paintings are never called wut even though they always include images of string bags and string-bag patterns.

Wut is used as the term for the painted, triangular palm-leaf head decorations that, according to contexts, either the initiates or the novices wear for dances on the ceremonial ground. Here, wut is an allusion to the initiation chamber within the ceremonial house where the novices are kept prior to their public appearance. Wut conjoins several different meanings and contexts. The string bag is the 'prototype' of all things visible and female and references what men keep concealed and secret; the two aspects - open and hidden-are co-present. Non-initiates, however, also know that each initiation grade has its own specific string-bag pattern that serves as its emblem. Women who enjoy making string bags know all these patterns and manufacture string bags for their husbands (occasionally for a brother) and for themselves, according to their husband's current initiation grade. 
With regard to technique, string bags and paintings have one thing in common, and that is maindshe, the 'string' or 'white line', respectively. The facade painting on a ceremonial house, for example, is based on an interconnected network of white lines. The head artist starts drawing a white line at the apex of the triangular-shaped facade, which has been primed with black paint and is lying flat on the ground. In the process of painting, further similarities to string-bag production become apparent: the white line is drawn unbroken from top to bottom so that in the end the surface is covered, and thereby structured, by a network of white lines (Hauser-Schäublin 1989b). ${ }^{14}$ The actual painting of the facade is done in horizontal bands equivalent to those formed by the looping technique used in making string bags. ${ }^{15}$ The bands have no centre point and no sides; actually, they are bands of ornament-style painting (see Stevens 1996). One of the main differences between string bags and painting is that, in painting, the large-sized motifs show figurative representations while on string bags the patterns consist exclusively of lines and geometric shapes (HauserSchäublin 1989b). Furthermore, painting is the work of specialists - that is, male artists - and is always kept secret from women and non-initiates, while string bags are manufactured by women, anywhere and at any time.

It is on the technological level - the creation of a network with the help of a line or a twine - that the analogy between painting and string bags becomes evident, but the two differ in terms of conditions of production and nomenclature; and this in turn references the significance of concealing and revealing in men's knowledge management.

The term wut also designates the womb - in other words, the 'bag' that contains the foetus (see also MacKenzie 1991:143-4). What all the concepts of wut have in common is that they represent containers of some form or another: string bags, a woman's 'bag' (in the sense of womb) and the initiation chamber. In its capacity as container, wut has the singular power to transform its contents (see also Losche 1997): a fetus grows to become a child in its mother's womb; an untamed piglet becomes a domesticated pig; in initiations, living men catch glimpses of the wondrous world of the ancestors and return 'impregnated with the beyond', while novices are transformed into knowledgeable men. None of these creatures comes out of wut the same as they went in; they all go through a condensed process of irreversible maturation and change. Wut possesses an agency, a generative power that transforms all creatures. In the secret male rituals staged in the ceremonial house, wut is again associated with femaleness. The association between the most important male spirits, nggwalndu, which are

14 The helpers contribute the red and yellow contours to the white lines, or fill them in.

15 The difference between the string bags of the Iatmul and those of the Abelam is that the former manufacture them by producing closed rings to which a new ring is then added, while the Abelam manufacture them in a continuous, spiral-shaped process (Schuster 1989:374). 
shown to the initiates in the painted initiation chamber, wut, and the string bag in the sense of womb - in Tok Pisin, both concepts go by the term 'bilum' - is also made by the Ilahita Arapesh (Tuzin 1980:244-5). There it is even stated explicitly that the bilum of the nggwal 'contains the children of all creatures, crying to be born' (Tuzin 1980:244).

In summary, one could say that the power of wut lies in the magic of transformation, the capacity to change irreversibly. This power is definitely female (see also Forge 1966:26); this also applies to the initiation chamber within which the novices transcend to a higher level of knowledge and attain a new social status; among other things, this transformation finds expression in the new name that the initiates receive when re-entering the secular realm of the village. What the adult men retain is, however, the social control over the whole process; this is shown in mythology, but, above all, it becomes evident in the incessant play of concealment and revelation.

\section{The Language of Concealing and Revealing}

The looping technique and the visual penetrability it produces-typical features of the string bag - create opportunities for the play of concealment and revelation. The two principles are also played out in a different field of Abelam culture - namely, in language and speech. Speaking in metaphors is a practice that enables people to keep ritual secrets concealed but hint at them all the same. In Tok Pisin, metaphorical speech is referred to as 'tok piksa'; in Abelam, as 'andsha-kundi'. Andsha-kundi is a ritualised form of speech that men use during ritual events held on the ceremonial ground (for example, mortuary feats, feasts held in the context of the yam cycle or during the construction of a new ceremonial house). Speakers revert to a wide range of metaphors to reference events and persons, but which only those informed are able to fathom.

As a speech form in its own right, andsha-kundi displays a specific structure. Similar to the looping technique in string-bag production, here 'loose ends' are twined and then looped into consecutive speech figures. Without announcement, the speaker begins with a seemingly meaningless sentence, hooks the next one on to it that makes just as little sense as the first, and so forth. It is only when these separate pieces are linked together that a meaningful speech figure begins to take shape. Here is an example of a song-speech performed by men (M) and women (F): ${ }^{16}$

16 Performed during a wake on 10 February 1979 at the ceremonial ground of Ndusaki in Kalabu. It is the song of Lake (Numbunggen hamlet, Kalabu). When these songs are performed, the women often contribute only the refrain; here they actually actively participate in creating the speech figure. 
M: You tell me to tie it up, and I tie it up.

F: You tell me to carry it, and I carry it.

M: These men are called Katu and Imagwate. They tie up a pig and carry it away.

F: These men Katu and Imagwate catch a cassowary and tie it up.

M: I have lucky hands.

F: Katu and Imagwate often catch pigs and cassowaries. They have lucky hands.

(Hauser-Schäublin 1989a:157)

The verse begins with an action - tying up - that someone has given orders for. In the following line, a second action-carrying an unnamed object-is added to the first. In the third line, the names of the actors are given; they refer to a pair of male ancestors (nggwal; in Tok Pisin: tambaran). By revealing their names, the speaker-singer discloses his identity as a member of the ritual ward associated with the two nggwal. At the same time, the listener hears what has been tied up and carried away: first a pig, and then a cassowary. The singer-speaker describes himself as a good hunter ('lucky hands'). In the two final lines, the singer reflects this self-portrayal onto his two nggwalndu, thus bringing to expression that the last were well disposed to him. At the same time, he is conveying the message that he is acting as the nggwal's proxy. ${ }^{17}$ Next to its specific texture, the constant back and forth between inside and outside and between concealing and revealing (see also Hauser-Schäublin 1992) plays a major role in this speech form.

In tok piksa, the metaphor of the string bag is a recurrent theme; it not only references a 'thing' or an 'object', it also actually refers to a complex interlinkage of actions. Let me explain this with a further example. On the occasion of the opening of a new ceremonial house in Kalabu in 1978, the men, in alternation with the women, ${ }^{18}$ struck up a song (nggwal mindsha) in honour of the most prominent nggwalndu of Kalabu, called Sagulas, in which they used the metaphor of wut to tell of his deeds.

M: I am under the water on earth. You may beat the slit-drum and call me. Then I shall set out to come and see you.

F: You must beat the slit-drum, then I shall appear in the village.

17 With this song-speech, the singer is promising the deceased that he will sacrifice a pig to honour him.

18 The men performed inside the ceremonial house while the women who sang the refrain stood outside, at the foot of the house's roof (Hauser-Schäublin 1989a:237-40). 
M: Sagulas is making a string bag.

F: I know, Sagulas is making a string bag with which one can catch the fishes kavi and mara.

M: When he is making the string bag, many men come to watch him at work. When he has finished the string bag, all are welcome to come and see it and rejoice in it.

(Hauser-Schäublin 1989a:237)

The song begins at the home of the nggwal Sagulas: a pool in the bush where he rests at the bottom. ${ }^{19}$ When the men start beating the slit-drums in the village (to start a ritual), he awakens and follows their call to the settlement. This is more or less the standard opening to all songs of this kind. Following this, two strands of action are inter-looped: the men sing of the nggwal who is making a string bag, which is then picked up and continued by the women who sing of manufacturing nets for catching fish. What the men really mean with the metaphor of making string bags is that Sagulas - that is, the men themselves - is busy producing secret things; in other words, painting ritual objects in preparation for an initiation. The women pick up this motif but give it a different turn, as men do not 'produce' string bags in the literal sense of the term. They describe the string bag as a fishing net. But, as one man explained, this phrasing actually means catching fish with one's bare hands and is a hidden reference to the final act in an initiation where the men indeed have to catch fish without the help of a net in a dammed stream. To what extent this reflects the men's interpretation of the wordage and in how far the women deduce the fish catch from the fact that Sagulas resides in water, I am unable to say with certainty. The constant back and forth between hinting at and then concealing again goes hand in hand with the reciprocal enactment of knowledge and not knowing between men and women.

\section{The Loops of the Tambaran and his String Bag}

In this section, I go on to show how the principle of concealment and revelation is enacted in the ritual life of men. I shall also address the problem once raised by Anthony Forge (1966) of the unresolved relationship between visual form, the names of single motifs in painting and their meaning in initiations, which I discuss from the perspective of the systemic qualities of the string bag. Forge's respondents gave him three different designations for the motif of the spiral:

19 As in the case of the other spirits, wale, the nggwalndu are said to reside in hidden pools and waterholes deep in the bush; these pools are regarded as passages to the world beyond, where the sun shines when it is night in the human realm. 
swirl in the water, leg of pork and fern frond. What Forge wanted to find out was: what did this heterogeneous terminology mean in the context of initiations? Why have three so completely different meanings, and, raising the question to the next level, is it actually possible to translate the visual into language, and what is the relationship between the two forms of communication (Forge 1970:289; see also Losche 1995, 1996, 2001)?

In a figurative sense, this type of partial visual penetrability that one encounters in string bags - the 'empty spaces' between the looped string - is also found on the facade painting, actually on the entire front of a ceremonial house. In a sense, the face of a ceremonial house, too, is not 'opaque'; it contains 'empty spaces' that allow 'glimpses' as well, thus reflecting one of the basic principles of the Tambaran cult among the Abelam. By this I mean, in analogy to the translucency of the string bag, the interplay between outside and inside. The elements shown on the front of a ceremonial house (including the motifs of the actual facade painting) function as hidden references to the various initiation stages and the secrets they incorporate, and thus operate in a similar manner to tok piksa, the metaphorical speech I described above.

In order to make this interplay between concealing and revealing clearer to the reader, I shall briefly outline the various initiation stages and the rituals that go with them - actually the only ritual events that are staged inside the cult house. At the time of my fieldwork in Kalabu, initiation among the Abelam consisted of an entire cycle of ranked grades; the completion of a full cycle could last up to several decades. ${ }^{20}$ Initiations always go hand in hand with the cultivation of long, ceremonial yams, the festive display of the finest tubers and the sacrifice of pigs. The first initiation grade is for young boys; the final stage is attained only by very few old men. Each initiation grade includes (apart from a series of rituals that the novices go through and, at times, week-long periods of seclusion) a cult scene that the initiators create inside the ceremonial house. The first grade is called nggumaira (nggu: 'stagnant water', maira: 'miracle', 'secret', often translated in Tok Pisin as tambaran). The created imagery consists of a hole that the men dig inside the ceremonial house and fill with water. ${ }^{21}$ The waterhole is covered with a layer of white foam (produced by triturating a special plant) on which the artists create a concentrically shaped picture with flowers and strips of leaves. ${ }^{22}$ The novices - all young boys - are escorted to the nggumaira in single file; after taking a brief glimpse at it, they are led away again and told to turn their backs on the 'miracle'. In the meantime, the men

20 At the time of my fieldwork, some initiation grades had not been staged for many years. My husband and I were able to witness some in neighbouring villages to which Kalabu men had been invited as guests. I shall continue to use the present tense when describing the different cult scenes although, as mentioned, these initiations are no longer performed.

21 The scene is based on the notion that the spirits reside in pools.

22 The strips are also referred to as maindshe, 'string' or 'streak'. 
cover up the image by throwing earth on it, making it look as if the ground has 'swallowed' the picture. Then the boys are told to turn round and look- the miracle has vanished!

For the second grade (ulke), double-sided carvings called ulke are lined up flanked by standing anthropomorphic male and female carved figures (wapinyan). Ulke is the term for predominantly female spirit beings, which are also associated with pools in the bush. The material secrets of nau, the third stage, consist of bizarre-shaped bamboo roots that are displayed upside down. The root ends often have the shape of birds' heads; the figures are frequently embellished by painting and adding feathers to them. Nau are considered to be female beings and are often decorated with women's adornments. Bamboo flutes (transverse flutes) represent the voices of the nau and are called nautagwa (nau: women). The female nau spirit beings live in treetops and have power over game animals (wild pigs, cassowaries), either driving them into or leading them away from the men hunting them.

Both grades - ulke and nau (by the time of my fieldwork they had been conflated into one single grade) — deal with female spirit beings associated with the 'wild' forest. The wood used for their representative carvings is taken from the lower ends and roots of plants, respectively.

The next two initiation grades are subsumed under the term 'nggwalndu'; ${ }^{23}$ their constituent parts are called nggilenggwal ('black' nggwal) and naranggwal ('decorated' nggwal). Nggwalndu are male ancestor spirits. Although each nggwal has a name of his own, individuality is of no significance; they are not distinguished in terms of outer image or behaviour. A nggwalndu initiation demands the staging of a feast with long ceremonial yams - namely, with the type called mambutap. Yam and nggwalndu stand in close relationship to each other. The yam tubers that are put on display each receive the name of a specific nggwalndu. The long yam is one of the many embodiments of these powerful spirit beings.

The nggwalndu initiation scenes are highly elaborate. The spirits are represented by massive carvings. In nggilenggwal, these consist of large faces to which occasionally a chest part is added. The carvings are placed upright and have tent-shaped backs attached to them, which are covered with plaited and painted mats. Nggilenggwal have neither arms nor legs. The figures are covered above by a mat-roofing called nggilut ('black string bag'). In front of the figure (occasionally there are several figures), the men lay out shell rings in a semicircle and stick bone daggers in the ground (both items are associated with stars). The semicircle is referred to as 'hole in the ground' so that, in fact, each nggilenggwal

23 Nggwalndu refers to ancestral spirits associated with the village as well as with a specific ceremonial ground and clan. The same term is used for 'grandfather' and 'stomach'. 
is shown sitting before, or even in, a waterhole. The voices of the nggilenggwal are sounded by singing into bamboo tubes sticking in a wooden cylinder (kundi ure). Naranggwal focuses on huge male figures cut from tree trunks. They are placed next to each other in the ceremonial house, reclining on a rack that has been erected parallel with the longitudinal axis. Above them is a painted canopy made of palm leaves sewn together. Above the canopy there is a hidden floor where the initiators take up position. The walls are also made of painted palm leaves, thus creating a fully decorated initiation chamber. It is called narut ('decorated string bag'). As in the case of nggilenggwal, here, shell rings are laid out in a semicircle in front of the figures; here, too, they indicate stars.

The name of the last initiation grade is puti. At the time of fieldwork, this grade had not been performed for something like 30 years. It is also called bikna, which is the name of a bird that lives and nests predominantly on the ground. In the past, this level was reached by only a few old men-partly for demographic reasons, but also because of the tremendous amount of pigs required for sacrifice. A man who had passed this grade enjoyed special status in his ritual moiety and his clan as well as in his ward and the village as a whole; he became a so-called numandu ('big-man'). The cult scene for this grade consists of a single figure that is placed-again, in the longitudinal axis - at the centre of the ceremonial house. Like nggilenggwal, it has a carved face; its body is made of a tent-like frame over which a finely plaited mat is laid and painted red, black, yellow and white. The outer surface of the tetrahedron-shaped body, which has the same shape as the ceremonial house itself, is decorated completely with shining white shell rings and likened to a bright, starlit sky.

The front side of the seated puti figure is fitted out with angled and raised arms and bent legs, made of banana stems. In its hands it holds spears, while its feet are equipped with the hoof-shaped claws of a cassowary. In front of the figure, again, shell rings are laid out in a semicircle. In contrast with the nggwalndu stages, here, there is no initiation chamber since now the interior of the ceremonial house as such is looked upon as puti's house-his wut. The term puti means effectively the 'empty one', 'he who has given everything'. The figure is compared with an old man sitting near a fire warming his skin in the ashes (see also Stöcklin 2004:Cover plate).

An experienced old man once commented on the initiation cycle with the words: 'nggumaira opens the door, puti closes it.' What he was saying was that, with puti, the world of mysteries and secrets has come to an end; ${ }^{24}$ there is no knowledge of what lies beyond; what is left at the end of the journey is simply the void.

24 In his three monographs $(1980,1997,2001)$, Tuzin describes and discusses the beings and their innate properties that the Ilahita Arapesh subsume under the term Tambaran, mainly with reference to myths. 
The principle upon which the succession of the various stages and the relationship between the different grades are based always follows the same structure: the initiating members of one ceremonial moiety dramatically enact and visualise knowledge about the mysteries and terrors of existence for the initiates of the opposite moiety. After subjecting the novices to a series of oftenpainful procedures and tests, the true nature of these mysteries and terrors are then revealed to them. In each stage, they are made to believe that this time they are going to encounter the real secrets and that they are about to take a next step into the intriguing world of the spirit beings who make the world go round and shape the fate of human beings. Consequently, with each stage, the scenes and ritual procedures become more complex - up to the end where a few men reach puti and encounter the void, the realm where all human knowledge ends.

\section{The System of Relating the Outside to the Inside}

Concealing and revealing are founded on the principle of ambiguity and implication - a system of signs that offers a broad range of interpretation. The signs themselves are not random in any way, and what applies to the Sagulas song-speech described above also goes for the constituent motifs of sacred imagery.

Many of the highly meaningful objects used in imagery are human-made and hand-shaped artefacts. These artefacts are ambiguous in the sense that they possess a public and a secret dimension - an 'outside' and an 'inside'. I discovered the loops between the 'outside' and the 'inside' - meaning the initiation grades - only when I began going through photographs of the Abelam collection from the Basel Ethnographic Museum whilst still in the field. After having worked for months with several old Abelam men - namely, artists - on the terminology and the meaning of the various objects, I suddenly realised that I had often recorded two terms. These terminological discrepancies first had me muddled. One of my closest co-workers, the artist (maira yagwandu) Kwandshendu, led me onto the right track when he explained: 'When you have a carving on the outside of the ceremonial house it has a special term, but when you use it inside the house for an initiation scene, it has a different name.' What Kwandshendu was describing was actually the visualised version of andsha-kundi (hidden speech); in other words, depending on the situation, the objects were referring to different action and meaning contexts and thus carried different names and significations. In fact, what Kwandshendu had explained to

What the Abelam call maira - literally, secret and mysterious - actually refers more to what lies behind the Tambaran. Of nggwalndu (ancestors, ancestor spirits), they say they are maira; however, the term maira does not denote a category of beings as such but rather their innate properties, the features that human beings are unable to fathom. 
me here - almost casually, in undramatic terms - was the relationship between the esoteric and the exoteric that becomes fused in the motifs of the facade painting and the various three-dimensional objects that adorn the face of a ceremonial house. This interconnection between the 'outside' and the 'inside' is known foremost to the maira yagwandu, the artists.

What surprised me about this explanation was the fact that the Abelam conceptualise the principle of concealing and revealing as a system in which all the visible, outside elements of a ceremonial house actually refer to secret, 'inside' contexts; and they put the system into practice knowingly. Until now, Melanesia specialists have usually assumed that it is up to the anthropologist to 'uncover' such a system and its working order, 'but [that it] does not involve the conscious corroboration by or intent of the users of the system' (Losche 2001:158). Kwandshendu's explanation clearly shows that-notwithstanding anthropological qualms and speculations - the indigenous artists (and other 'big-men') are fully aware of the linkage between motif and object, and between term and function. With this, he also provided an answer to Anthony Forge's question. Meaning is defined by context, and terminology is therefore not determined by the object or the motif, but by the circumstances. When Kwandshendu went through the visible signs on the ceremonial house with us, it became clear that Abelam men 'read' the front of a cult house as a system of signs, which, at the same time, serves as a mnemonic device to register the single grades in initiation.

Painting is a self-contained part of this system. The single bands and the motifs shown on the facade serve as signs that have distinctive names and allow room for differing interpretations. In its total structure, a facade painting reflects the sequential order of the initiation grades and the way they are interrelated. A facade painting is created from top to bottom and this is also the way it is viewed and read: the topmost rows of motifs refer to cult scenes that are centred on the forest as the abode of mysterious creatures and spirit beings that live in pools or in treetops. The apex of the painting shows a flying fox (matmboi); it is classified as a female being that lives in the tops of trees and tries to confuse hunters below; matmboi serve as references to the nau initiation grades. Beneath the flying fox there follows a variegated array of spirals. This is the motif for which Anthony Forge noted the three differing terms (see above) and which had him rather confused and, later, inspired Diane Losche (1995) to venture new interpretations. In Kalabu, and in the context of initiations, the spirals are interpreted as the traces of water spiders scurrying over the surface of a pool or as 'rippled water surface' and 'foam', respectively. They reference the first initiation grade, nggumaira, where a foamy image is created on the surface of a waterhole, as well as ulke spirits and the pools where these female beings are said to reside. The next band of motifs shows female bats (kwandshe) with 
their young (kumbui) clinging to their breasts. These bats refer to female spirits that glide silently through the bush, not unlike witches, the people say; they represent the central figures in the cult scene of the ulke initiation grade. The band showing the black-red fruits and the pair-wise grouped spirals are also associated with the mysterious realm of the forest and its inhabitants; the latter represent birds (of the maintshe or baintship species, respectively). The band displaying the splendidly decorated dancers (the motif is called ndudama) is a reference to what the Abelam believe to be the most significant and greatest maira of all - that is, men in full ceremonial adornment. The dancers who have their eyes shut are described as having just returned from the mysterious and splendid world of the beyond, still mesmerised by the beauty and the miracles they saw there. Finally, the eye comes to the bottom row with its huge faces and the minute zigzagging bands that depict the figures' arms and legs (the motif is called nggwalnggwal); the figures represent the nggwalndu class of ancestral spirits. The string bag patterns encompassing them are emblems of the nggwalndu initiation grade and thus also signify the painted initiation chamber in the naranggwal grade, called narut.

The facade painting is like a kaleidoscopic image consisting of rows of motif bands that can be conflated to create different images, all depending on who the viewers are, what their level of knowledge is, and what perspective they are viewing it from. Accordingly, the motifs refer to different things with alternative meanings to different viewers.

Unlike the two-dimensionality of conventional painting, which relies on the consistent medium of colour, the visible face of a ceremonial house with all its ambiguous elements of different shapes and material constitutes a threedimensional work of art that intricately enacts the esoteric and the exoteric. As described above, the first initiation grade, nggumaira, involves only perishable material and is therefore not expressed by a permanent image on the outside representation. The only reference to this ephemeral cult scene is a narrow, waved band showing small, colourful fruits and leaves (mindshakuso) located below the carved crossbeam on the lower exterior. The same type of band encompasses the actual nggumaira image created over the artificial pool inside the ceremonial house.

All the other initiation grades that rely on comparably durable objects for their specific cult scenes are represented on the visible face of the ceremonial house as follows. The ulke initiation, including the homonymous carvings, is represented by the carved crossbeam located beneath the facade painting and described in this context as tikik. The nau initiation is signified by the birds' heads made of bamboo roots and located on the inside of the protruding side walls - that is, the roof of the house; here they are designated vi warya. The tunnel-shaped entrance (korekore) to the ceremonial house references the entry to the initiation 
chamber inside (atapine), while the carved pythons (ndua), which are usually located above the korekore, indicate the places of origin of spirit beings (wale) that play a role in several, different initiation scenes.

Nggilenggwal, or to be more precise, the plaited initiation chamber (nggilut), is represented by the plaited mat (kimbi) located at the lower end of the face of the cult house. The spears (vi) stuck into the projecting roof are also a reference to this grade. Inside the house, similar spears are placed over the corridor that leads to the initiation chamber, with their pointed ends aimed at the novices.

Naranggwal, in which the colourfully painted initiation chamber (narut) plays an important role, is first and foremost referenced by the large facade painting (mbai) itself. During the naranggwal initiation, a raised - that is, suspendedfloor, actually the roof of the initiation chamber, is constructed where the initiators position themselves and imitate spirit voices (with the help of musical instruments). For its construction, the men use thick vines, which they refer to as samban in this specific context - that is, in the interior of the ceremonial house. Similar vines can be found on the outside of the cult house - to be more specific, winding themselves up on the inside of the extended walls and ending high up under the protruding roof peak. Here the vines are referred to as narkassa.

The last initiation stage, puti, described as an old man whose back is formed by the star-covered sky, the cosmos, is signified by the ceremonial house (korambo) as a whole. As such the ceremonial house also stands for the entity that contains all the secrets and miracles that the novices have come to see in kaleidoscopic imagery in the course of the initiation cycle over the past years. When a new ceremonial house is inaugurated, the front, matted, lower section of the house is decorated with shell rings; above them is exhibited a selection of the most beautiful string bags made especially for the occasion by the women. Puti and the ceremonial house stand in a microcosm/macrocosm relationship to each other. One should also add here that the ceremonial house with its sloping ridge (designated simultaneously as nyit, 'sky', and yapa, 'father') bears reference to the western realm of the cosmos and is aligned to the course of the setting sun. ${ }^{25}$

25 To describe the complex semantics and the cross-referencing between cult house and ceremonial ground and their specific decorative elements would be beyond the scope of this chapter (but see Hauser-Schäublin 1989a:285-302). 


\section{Concealing and Revealing as Hallmarks of the Unexplainable}

The secrets that men conceal and then reveal in rituals relate to a transcendental mode of perception and understanding of phenomena that cannot be explained in any other way. The impressive images created by the assemblage of variegated objects and artefacts reference notions and concepts that lie beyond the boundaries of their own innate logic; they bear on matters that lie hidden away and will, in essence, always remain inaccessible and enigmatic. They address issues such as the diversity of existence in the world, the origins of this existence, life and death, as well as modes of regeneration to overcome death.

Concealment and revelation constitute an idiom of intimations, a form of communication that does not offer explanations, but instead provides glimpses of ever-changing combinations of single elements and phenomena in kaleidoscopic fashion. For the Abelam, the unexplainable has always been a part of everyday life: unexpected encounters in the garden, down at a stream or deep in the bush; a wild pig suddenly dashing out of the dense undergrowth a few feet in front of the hunter; a flying fox with outstretched wings gliding soundlessly over somebody returning from the garden in the twilight; a snake vanishing stealthily into an overgrown pool; shooting stars falling from the sky but never hitting the ground; small yam cuttings, almost withered away, growing to become magnificent tubers; a wife no longer issuing menstrual blood, and instead a child grows in her belly. Such and many similar phenomena are experienced as facets of a reality that, in the end, is not fathomable and will always remain a mystery. The people look upon it as a transcendental reality that shows itself only in bright but brief glimpses. Prism-like, the pieces join together to reveal a kaleidoscopic picture, an image, however, that keeps changing according to its innate properties as well as to the perspective of the viewer.

Men sometimes dream of unexplainable phenomena and discuss them with others in meetings at the ceremonial ground in a joint search for answers to matters that do not immediately reveal themselves. They are looked upon as signs that point to hidden realms of being.

Ritual life and the ceremonial house represent specific forms of organising and shaping the relationship between humans and their transcendental reality. On this stage, the living play the part of the 'non-initiated' who are barred from discovering the ultimate secret, just as the women and children are excluded from the secrets of men, and, vice versa, the men are banished from the female realm of menstruation and giving birth (see Hauser-Schäublin 1995). This secluded world with its own logic and powers reveals itself only through signs and clues, which the old men try to catch hold of in cult scenes. What characterises the 
relationship between the concealed and the revealed is the co-presence of both 'worlds': the visible and the invisible. What lies concealed and reveals itself in fleeting glimpses and ephemeral images does not exist in a time frame that is separate from the here, now and then. Concealing and revealing constitute a mode of dealing with, and mediating, co-presence (Hauser-Schäublin 1997). In spatial terms, the cult house and the ceremonial ground create an interface between the realms of the visible and the invisible (Hauser-Schäublin 2003). This junction is a powerful and dangerous place and demands special modes of conduct. If people misbehave, no matter whether they are men, women or youths, the 'old folk' (golepa) impose sanctions; at least this is the way that men commonly explain unexpected blows of fate.

\section{Conclusion}

During initiation rituals, the initiating men from the one ritual moiety often terrorised the novices of the opposite moiety, or at least put fear into them by threatening them with terrible ordeals; it was part of the 'game'. In conjunction with the interplay of concealing and revealing, the knowledgeable were able to retain power over the unknowledgeable. The use of power and terror did not, however, split the world of men into durable categories of superiors and inferiors; instead, here again we encounter the principle of continuous looping - social looping, this time - since the novices of the one moiety later became the initiators of the neophytes of the other ritual half, and so forth, in an ongoing process of interchanging roles. ${ }^{26}$ The two ritual halves stood in a continuous, competitive exchange relationship that found expression through various channels such as yam and pig feasts, initiations and the construction of ceremonial houses. The representations that were created and enacted in initiations were not made for their own sake nor was the concept of concealment and revelation merely an instrument of social control based on multiple forms of 'deception' - hoodwinking the non-initiates - as the confession by the men of Ilahita might suggest. This would be taking a very short view of things.

Moreover, the mode by which the enigmatic was organised and mediated also served as the basis of the social system, relying on structures and processesso far, my initial hypothesis - that were also modelled on the principle of concealment and revelation. We have here a segmentary concept that creates nested divisions of knowledgeable and unknowledgeable on the basis of exclusion, integration and inclusion: the men were ignorant of the secrets of women; children and women had no knowledge of the secrets of men; and young 26 See Losche (2001) on the interlocked ritual exchange relationships between the initiators of one
ceremonial moiety and the novices of the opposite half. 
men - graded according to initiation level — were nescient of the knowledge of the older, enlightened men, with the enactment and mediation of knowledge oscillating between the two ritual moieties.

The relationship between human beings and the world beyond, and the mode in which the Abelam conceptualised and shaped this bond, created the screen on which the interplay between concealing and revealing was enacted as a means to create hierarchies of knowledge in society, while at the same time it formed the loops that held all the segments together.

I doubt whether Ilahita Arapesh men were ardent nihilists or merely great theatrical actors attempting to keep the ignorant unwitting and under control, as a reader might infer from Tuzin's (1997) description. When the men declared that the Tambaran had been nothing but lies and deception, they were in fact addressing only one aspect of representation - namely, the notion of concealment (and revelation) vis-a-vis women and children. In view of the findings presented here, one should really reassess the 'killing of the Tambaran' as recounted by Tuzin and also reconsider the two episodes described above where some young Abelam men voiced their protest against the 'law of the past'. What the Christian revivalists described with hindsight as the 'old men's sleight of hand' was only half the truth. In fact, the conceptual background upon which the principle of concealment and revelation was founded - the netherworld beyond that revealed itself in bright flashes and brief episodes-had simply run its course in the eyes of the revivalists (and others in the Maprik area), replaced with promises that the Holy Spirit was ready to deliver to believers instant salvation and riches. What yet stood in the way of Salvation was the old, ever co-present world of spirits that was considered evil (see also Reithofer 2006:Ch. 4; Strong 2007), and for this 'the Tambaran had to die' (Tuzin 1997:64). The prophecies heralded an end to all toils and the advent of a paradisiacal world, not in distant days to come, but now, in the immediate future. The rituals staged by the Christian revivalists were geared to transforming the future into the present. Tuzin tells of a

tiny repertoire of maddeningly repetitive, largely tuneless hymns... The blaring incessancy of the hymns quickly became for us a kind of torture...Continuing long into the night and resuming at first light, these hymns were sounding when we went to bed, sounding when we woke up, churning whatever sleep we achieved during the long hours of the service. (Tuzin 1997:222-3)

It seems that the 'second coming' had to be sung into existence, that the tomorrow should become today. 
The group of believers included both men and women, headed by prophetic service leaders. The revivalists distanced themselves from non-believers or members of other denominations in a more general sense of the term, but drew a strict dividing line between themselves and the so-called 'traditionalists'. The Holy Spirit's cornucopia would not come in the shape of a string bag; instead it was to contain trucks and aircrafts (Tuzin 1997:149-50). The riches were to come as money and cargo, not as fertility and regeneration.

This new world of belief and thought rested on a completely different foundation; it was embedded in global relations and transactions, in ideas of progress, development and Western capitalism, and demanded from the people a completely new orientation and perspective (Sahlins 2005). The 'confessions' made by the revivalists in Ilahita and the demands that the young Abelam men confronted me with during my fieldwork actually show that people had begun to alter their orientation and to adjust to the demands of a changed and changing world. The values fostered by the old men and embodied by the string bag of the Tambaran with its incessant and systemic loops of concealing and revealing no longer sufficed as a canon on which people could model their identity.

The string bag had become riddled with holes; its loops had come apart. It was no longer able to contain what it had held before-neither the two copresent 'worlds' nor the social order that relied on the segmentary principle of exclusion and inclusion and which was fuelled by concealment and revelation. The groups over which the agents of the Tambaran in earlier days had wielded power through the string bag - the young men and the women-firmly took possession of their newly gained freedom (as the opening passages of this chapter showed), moving into new fields of action, well beyond the reach and the 'revenge' of the cassowary.

\section{References}

Coupaye, Ludowic 2004. Growing Artefacts, Displaying Relationships: Outlining the Technical System of Long Yam Cultivation and Display among the Abelam of Nyamikum village (East Sepik Province, Papua New Guinea). Unpublished Ph.D. dissertation. Norwich, UK: University of East Anglia.

Forge, Anthony 1966. Art and Environment in the Sepik. Proceedings of the Royal Anthropological Institute of Great Britain and Ireland 1965:23-31.

Forge, Anthony 1970. Learning to See in New Guinea. In P. Mayer, (ed.) Socialisation: The Approach from Social Anthropology, pp. 269-91. New York: Tavistock. 
2. The String Bag of the Tambaran: The fragile loops of concealing and revealing in Abelam culture

Forge, Anthony 1971. Marriage and Environment in the Sepik: Comments on Francis Korn's Analysis of Iatmul Society. In R. Needham (ed.) Rethinking Kinship and Marriage, pp. 133-44. London: Tavistock.

Forge, Anthony 1972. The Golden Fleece. Man 7:527-40.

Forge, Anthony 1973. Style and Meaning in Sepik Art. In Anthony Forge (ed.) Primitive Art and Society, pp. 169-92. London: Oxford University Press.

Gewertz, Deborah and Frederick Errington 2004. Toward an Ethnographically Grounded Study of Modernity in Papua New Guinea. In Victoria S. Lockwood (ed.) Globalization and Culture Change in the Pacific Islands, pp. 273-84. Upper Saddle River, NJ: Pearson Prentice Hall.

Goankar, Dilip Parameshwar 1999. On Alternative Modernities. Public Culture $11: 1-18$.

Hauser-Schäublin, Brigitta 1989a. Kulthäuser in Nordneuguinea. Berlin: Akademie-Verlag.

Hauser-Schäublin, Brigitta 1989b. Leben in Linie, Muster und Farbe. Einführung in die Betrachtung außereuropäischer Kunst am Beispiel der Abelam. Basel: Birkhäuser.

Hauser-Schäublin, Brigitta 1992. Der verhüllte Schrein. Sakralarchitektur und ihre Umhüllungen in Bali. Ethnologica Helvetica 16:171-200.

Hauser-Schäublin, Brigitta 1995. Puberty Rites, Women's Naven, and Initiation. In Nancy Lutkehaus and Paul Roscoe (eds) Gender Rituals: Female Initiation in Melanesia, pp. 33-53. New York and London: Routledge.

Hauser-Schäublin, Brigitta 1996. The Thrill of the Line, the String, and the Frond, or Why the Abelam Are a Non-cloth Culture. Oceania 67:81-106.

Hauser-Schäublin, Brigitta 1997. Die Vergangenheit in der Gegenwart: Zeitkonzeptionen und ihre Handlungskontexte bei den Abelam in PapuaNeuguinea. Baessler-Archiv (NS)45:409-29.

Hauser-Schäublin, Brigitta 2002. Gender: Verkörperte Feldforschung. In Hans Fischer (ed.) Feldforschungen: Erfahrungsberichte zur Einführung, pp. 73-99. Berlin: Reimer.

Hauser-Schäublin, Brigitta 2003. Raum, Ritual und Gesellschaft: Religiöse Zentren und Sozio-religiöse Verdichtungen im Ritual. In B. Hauser-Schäublin and M. Dickhardt (eds) Kulturelle Räume-Räumliche Kultur: Zur Neubestimmung des Verhältnisses zweier fundamentaler Kategorien menschlicher Praxis, pp. 43-87. Münster: LIT. 
Hirsch, Eric 2001. When Was Modernity in Melanesia? Social Anthropology 9:131-46.

Ingold, Tim 2007. Lines: A Brief History. London: Routledge.

Jourdan, Christine 1996. Where Have All the Cultures Gone?: Sociocultural Creolisation in the Solomon Islands. In Jonathan Friedman and James G. Carrier (eds) Melanesian Modernities, pp. 34-52. Lund, Sweden: Lund University Press.

Losche, Diane 1995. The Sepik Gaze: Iconographic Interpretation of Abelam Form. Social Analysis 38:47-60.

Losche, Diane 1996. The Impossible Aesthetic: The Abelam, the Moa Bird and Me. Oceania 66(4):305-10.

Losche, Diane 1997. What Do Abelam Images Want from Us?: Plato's Cave and Kwatbil's Belly. The Australian Journal of Anthropology 8:35-49.

Losche, Diane 2001. Anthony's Feast: The Gift in Abelam Aesthetics. The Australian Journal of Anthropology 12:155-65.

MacKenzie, Maureen 1991. Androgynous Objects: String Bags and Gender in Central New Guinea. Chur, Switzerland: Harwood Academic.

Reithofer, Hans 2006. The Python Spirit and the Cross: Becoming Christian in a Highland Community of Papua New Guinea. Göttinger Studien zur Ethnologie 16. Münster, Germany: LIT.

Roscoe, Paul B. 1995. Of Power and Menace: Sepik Art as an Affecting Presence. Journal of the Royal Anthropological Institute (NS)1:1-22.

Sahlins, Marshall 2005. The Economics of Develop-man in the Pacific. In Joel Robbins and Holly Wardlow (eds) The Making of Global and Local Modernities in Melanesia, pp. 23-42. Hampshire, UK: Ashgate.

Scaglion, Richard 1999. Yam Cycles and Timeless Time in Melanesia. Ethnology 38:211-25.

Schuster, Gisela 1989. Netztaschen der Zentral-Iatmul im Museum für Völkerkunde Basel. In Beate Engelbrecht and Bernhard Gardi (eds) Man Does Not Go Naked. Textilien und Handwerk aus afrikanischen und anderen Ländern, pp. 335-89. Basel, Switzerland: Wepf.

Stevens, Peter S. 1996. Handbook of Regular Patterns: An Introduction to Symmetry in Two Dimensions. Cambridge, Mass.: MIT Press. 
2. The String Bag of the Tambaran: The fragile loops of concealing and revealing in Abelam culture

Stöcklin, Werner 2004. Toktok: Am Rande der Steinzeit auf Neuguinea. Basel, Switzerland: Friedrich Reinhardt.

Strong, Thomas 2007. 'Dying Culture' and Decaying Bodies. In Sandra Bamford (ed.), Embodying Modernity and Post-Modernity: Ritual, Praxis, and Social Change in Melanesia, pp. 105-23. Durham, NC: Carolina Academic Press.

Tuzin, Donald 1980. The Voice of the Tambaran: Truth and Illusion in Ilahita Arapesh Religion. Berkeley: University of California Press.

Tuzin, Donald 1997. The Cassowary's Revenge: The Life and Death of Masculinity in a New Guinea Society. Chicago: University of Chicago Press.

Tuzin, Donald 2001. Social Complexity in the Making. London: Routledge. 